\title{
Denitrification Potential and Denitrifier Abundance in Downstream of Dams in Temperate Streams
}

\author{
Nguyen Xuan Que Vo, Seung-Hoon Lee, Tuan Van Doan, Sokhee P. Jung, and Hojeong Kang* \\ School of Civil and Environmental Engineering, Yonsei University, Seoul 120-749, Republic of Korea
}

\section{온대지역 댐 하류의 탈질화 능력과 탈질화균 분포}

\author{
Nguyen Xuan Que Vo · 이승훈 · Tuan Van Doan · 정석희 · 강호정* \\ 연세대학교 토목환경공학과
}

(Received April 3, 2014 / Accepted May 26, 2014)

\begin{abstract}
Various studies have been conducted to investigate effects of dams on river ecosystems, but less information is available regarding damming impacts on downstream denitrification. We measured denitrification enzyme activity (potential denitrification rate) and denitrifier abundances (using nirS, nirK, and nos $Z$ as markers) in dammed headstreams of the Nakdong River in South Korea. Sediments in Phragmites-dominated riparian areas and in-stream areas across streams (dammed vs. reference) with different streambed materials (gravel and sand) were sampled occasionally. We hypothesized that (i) the higher available $\mathrm{N}$ and $\mathrm{C}$ contents in sediments downstream of dams foster larger denitrifier communities than in the reference system and (ii) differences in potential denitrification rates across the systems correspond with denitrifier abundances. Despite 30 years of different hydrological management with dams and greater inorganic $\mathrm{N}$ and DOC contents in sediments downstream of dams, compared to the references, abundances of denitrifier communities and potential denitrification rates within the whole sediment were not significantly different across the systems. However, nirS and nos $Z$ denitrifier abundances and potential denitrification rates were considerably increased in specific sediments downstream of dams (gravelly riparian and sandy in-stream) with regard to flooding events and seasonal temperature variation. nirK was not amplified in all sediments. Canonical correspondence analyses (CCA) revealed that the relationship between abundances of denitrifier communities and nutrient availabilities and potential denitrification rates was a weak one.
\end{abstract}

Keywords: denitrification enzyme activity, denitrifier abundance, nitrogen cycle, stream regulation

Current uncertainty in water management strategies, namely additional dam construction versus dam removal, has raised the question whether we should reevaluate the effectiveness of management strategies of water resources in terms of economic, social and environmental costs. Hydrological transport processes and their temporal variations are ubiquitous features of running-water ecosystems across multiple spatial scales (Kondolf et al., 2006; Fisher et al., 2007). Flood control through the construction of dams on rivers or streams has intensively altered downstream flow regimes, changing the timing, magnitude, frequency and current velocity of high and low flows (Grant et al., 2003); consequently, restricted the exchangeable flows of substrates and energy between subsystems, for example

*For correspondence. E-mail: hj_kang@yonsei.ac.kr; Tel.: +82-2-21235803; Fax: +82-2-364-5300 between the main channel and floodplain or riparian zones (Gergel et al., 2005). Thus, the damming of rivers necessarily results in downstream changes in water quality (temperature, oxygen and nutrient concentrations), energy sources (organic matters of both riverine and in situ origin), physical habitats (sedimentation and the expansion of nonnative riparian plants) and biotic interactions (Friedl and Wüest, 2002; Grant et al., 2003; Genkai-Kato et al., 2005; Burke et al., 2009). River regulation by dams, thus, provides a dramatic example of the anthropogenic disruption of biogeochemical cycling of nutrients such as the alteration of denitrification, which is an important nitrogen removal process in river systems (Vitousek et al., 1997; Burgin and Hamilton, 2007).

A global overview of the effects of dams on the river flow regime and channelization of more than 292 largest river systems showed that more than half of them were strongly 
affected, which include eight of the most biogeographically diverse systems in South America, Africa, and Asia (Nilsson et al., 2005). Even so, precise knowledge of the functional processes of rivers in response to dam-induced disturbances remains unclear. Denitrification is the critical biological process in determining contributed amounts of nitrogen within a river system (Mulholland et al., 2008). In many cases, researchers have observed the increasing amounts of bioavailable nitrogen to enter rivers together with uncoupling low in-stream N levels (Boyer et al., 2002; Mulholland et al., 2008). As such, numerous empirical measurements of denitrification rates in the sediments of a range of natural aquatic ecosystems (rivers, streams, lakes, and coastal marines) have been conducted to evaluate such a fundamental process (Seitzinger et al., 2006; Wallenstein et al., 2006). In natural streams, denitrification often accounts for a great portion of the total nitrate removal (Mulholland et al., 2008). However, estimates of denitrification in disturbed streams and rivers, such as dammed systems, have been rarely reported (Strauss et al., 2006; Pinardi et al., 2009; Welti et al., 2012).

Denitrification is the stepwise biological reduction of nitrate, nitrite and nitric oxide to nitrous oxide or nitrogen gas via four enzymatic complexes (Zumft, 1997). Phylogenetically heterogeneous microorganisms use this respiration pathway as an alternative in the absence of oxygen (Philippot and Hallin, 2005). The availabilities of nitrate and organic carbon are thus important in determining denitrifying activity in soils (Starr and Gillham, 1993; Philippot et al., 2007; Enwall et al., 2010). Denitrification usually occurs at oxic/suboxic interfaces, where higher nitrate concentrations and abundant denitrifiers (mostly facultative anaerobes) can exist (Seitzinger et al., 2006). However, the occurrence of denitrification in a wide range of ecosystems revealed in previous studies implied the diverse environmental conditions for denitrifying activity (McClain et al., 2003; Seitzinger et al., 2006). The environmental factors affecting denitrification have been identified in many field studies. For example, denitrification rates can be strongly influenced by soil moisture and temperature (Groffman et al., 1996; Stres et al., 2008), as well as soil texture (Davidsson and Stahl, 2000; Pinay et al., 2000; Solomon et al., 2009; Enwall et al., 2010). These controlling variables are universal but drive denitrification to different extents at different spatial and temporal scales (Hill et al., 2000; Skiba and Smith, 2000).

Denitrifiers are a phylogenetically diverse group with large variations in physiology and life history traits (Zumft, 1997). That is, denitrifier species differ in the way they respond to the environment (Stevenson and Schmidt, 2004; Jones et al., 2008). For example, they do not all have the same optimal temperature for growth (Philippot and Hallin, 2005). Denitrifier communities are therefore likely to change in response to the selective pressures imposed by the anthropogenic disruption, such as river impoundment in this instance. Nevertheless, most denitrifiers are facultative anaerobes, using nitrate as the next best alternative electron acceptor for oxygen under hypoxic or anoxic conditions. Previous studies on denitrifier communities have used functional genes (nirS, nirK, norB, and nosZ) as genetic markers for the analysis of denitrifier abundance, diversity or functional gene expression (Zumft, 1997; Philippot et al., 2007; Huang et al., 2011). Among them, the nir genes encoded for a cytochrome cd1 (nirS) or a $\mathrm{Cu}$-containing enzyme (nirK) catalyzing the reaction to reduce $\mathrm{NO}_{2}{ }^{-}$to nitric oxide (NO). The nir genes were widely targeted as important markers distinguishing denitrifier community from other $\mathrm{NO}_{3}{ }^{-}$ reducing bacteria. The nor $B$ gene encoded for NO reductase catalyzing the third step to reduce $\mathrm{NO}$ to nitrous oxide $\left(\mathrm{N}_{2} \mathrm{O}\right)$, a potent greenhouse gas that exacerbates climate change and stratospheric ozone destruction (IPCC, 2007). The last step is to reduce $\mathrm{N}_{2} \mathrm{O}$ to nitrogen gas $\left(\mathrm{N}_{2}\right)$, which is catalyzed by $\mathrm{N}_{2} \mathrm{O}$ reductase encoded by the nos $Z$. Recent phylogenetic analysis of the $n o s Z$ revealed two distinct clades, which mainly differ in the translocation pathway of nitrous oxide reductase across the membrane (Jones et al., 2013). Approximately one-third of the denitrifying bacteria capable of reducing nitrite cannot reduce $\mathrm{N}_{2} \mathrm{O}$ due to the lack of nosZ (Jones et al., 2008). This is important since the proportion of denitrifiers lacking $n o s Z$, as well as the ratio between the abundance of nitrite reductase genes and nos $Z$, may directly influence the ratio of $\mathrm{N}_{2} \mathrm{O}$ to $\mathrm{N}_{2}$ produced by denitrification (Philippot et al., 2011).

Abundances of denitrifier community have been quantified based on quantitative real-time PCR techniques in a wide range of environments, including riparian and wetland soils (Peralta et al., 2010; Song et al., 2010; Dandie et al., 2011; Ligi et al., 2013) as well as stream, river and estuarine sediments (Dong et al., 2009; Knapp et al., 2009; Graham et al., 2010; Huang et al., 2011). However, the links between abundances of denitrifier community and environmental conditions, as well as their activities, are rarely described, although improved molecular approaches has been expanded (Enwall et al., 2010). Recently, Philippot et al. (2009) reported that the abundance of nirS-harboring denitrifier related to soil $\mathrm{pH}, \mathrm{NH}_{4}{ }^{+}, \mathrm{NO}_{3}{ }^{-}$ concentration and soil water content. On the other hand, the attempts to relate the abundance of denitrifier communities to denitrifying activities have created mixed results. While some studies showed that denitrifier abundances have little or no effect on denitrification rates (Philippot and Hallin, 2005; Dandie et al., 2007, 2008, 2011; Cao et al., 2008; Miller et al., 2008), several others reported the opposite trend (Dong et al., 2009; Hallin et al., 2009; Philippot et al., 2009; Enwall et al., 
2010). Given the polyphyletic nature of denitrifying organisms, it is not surprising that drawing a global link between the denitrifier community, as well as their activities, and environmental conditions is not straightforward (Enwall et al., 2010). PCR-based assays are usually used to capture the majority of functional groups of organisms that have the same role in the ecosystem (Rastogi and Sani, 2011). The spatial variations of microbial assemblages due to contemporary environmental factors (niche-based processes) thus can be described.

We conducted a study of denitrification processes in downstream areas of dams in headwater streams of the Nakdong River, South Korea. Particularly, we aimed 1) to examine variations of sediment quality of downstream fluvial habitats, 2) to quantify denitrification enzyme activities (potential denitrification rates) and the abundances of denitrifier populations (nirS-, nirK-, and nosZ-bearing denitrifiers) and 3) to evaluate the link between environmental parameters and the density of denitrifiers, as well as their activity. The hypothesis was that upstream water discharge regulation from dams would change the quality of downstream sediments by increasing substrate availabilities for microbial communities and in turn enhances the potential denitrification rates.

\section{Materials and Methods}

\section{Study site}

We selected two dam-affected sites, one downstream from Imha Dam $\left(595 \times 10^{6} \mathrm{~m}^{3}\right.$ volume, constructed in 1992) and the other downstream from Andong Dam $\left(1,248 \times 10^{6} \mathrm{~m}^{3}\right.$ volume, constructed in 1976), located in the upper reaches of the Nakdong River. These dams are used for water supply storage, flood control and power generation. A relatively constant discharge of $10-30 \mathrm{~m}^{3} / \mathrm{sec}$ has been released from these dams over the year except in summer (July-September). During the summer period, the dams have released up to $47-60 \mathrm{~m}^{3} / \mathrm{sec}$ (Korea Ministry of Land, Infrastructure and Transport). The gravelly sampling site downstream of Imha Dam, Site $S_{1}\left(36^{\circ}\right.$ $\left.31^{\prime} \mathrm{N}, 128^{\circ} 51^{\prime} \mathrm{E}\right)$, was compared to the reference site in the Gilan tributary, Site $\mathrm{R}_{1}\left(36^{\circ} 31^{\prime} \mathrm{N}, 128^{\circ} 50^{\prime} \mathrm{E}\right)$. The sandy site downstream of Andong Dam, Site $S_{2}\left(36^{\circ} 33^{\prime} \mathrm{N}, 128^{\circ} 39^{\prime} \mathrm{E}\right)$, was compared to the reference site in the Naesung tributary, Site $\mathrm{R}_{2}$ $\left(36^{\circ} 37^{\prime} \mathrm{N}, 128^{\circ} 29^{\prime} \mathrm{E}\right)$ (Fig. 1). Hence, we could investigate one dam-affected site and one reference site for each sediment type.

Dam-affected sites were differentiated from reference sites according to the degree of the invasion of terrestrial plants into former floodplains. A detailed vegetation survey at the sampling sites was conducted by Cho et al. (2012). This survey found that the riparian vegetation extended widely near low water channel after the dam construction. The vegetation area at dam-affected sites, but not at reference sites, increased from 7\% of the total floodplain zone in 1988 to $44 \%$ in 2009 mainly due to the regulation of magnitude and frequency of flow regime from the upstream dams (Cho et al., 2012). Channel incision was also observed as a regular trend of river adjustment downstream of dams in South Korea (Choi et al., 2005). A few small mid-stream islands (area less than $4 \mathrm{~m}^{2}$ ) in various stages of development, regarding to the level of

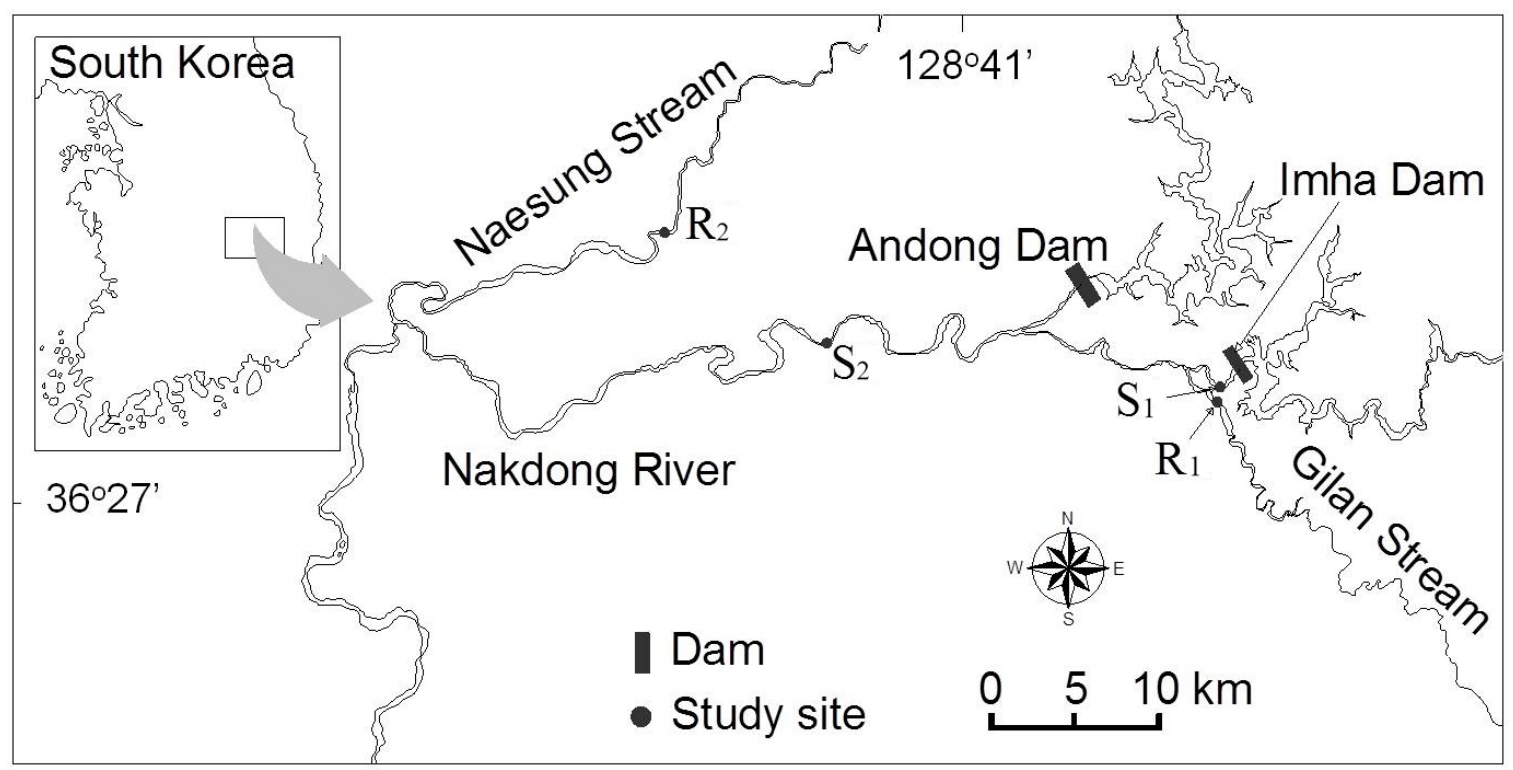

Fig. 1. Map of the sampling sites located in the Nakdong River. $S_{1}$ and $S_{2}$ represent the sampling sites downstream of Imha and Andong Dam, respectively, whereas $R_{1}$ and $R_{2}$ denote the reference sites. 
vegetation coverage, were observed at dam-affected sites, but not at reference sites.

The Nakdong River Basin is in a temperate climate region with four distinct seasons. The annual mean precipitation in the region is around 1,231 $\mathrm{mm}$ (basin average). Much of the annual precipitation falls between June and September as monsoon storms frequently begin in late June, causing flooding in the region. Agricultural lands cover a large portion of land use in the Nakdong River Basin. The extensive use of agricultural fertilizers was prevalent in the 1970s and had been cut off in 1991 (Chun et al., 2001).

\section{Sampling and biological and physicochemical analysis}

Sediment was sampled in September 2008, January 2009, May 2009, and August 2009 representing periods of different water discharges (Fig. 1). In each sampling site, we collected duplicate samples from the sediment surface to a $10 \mathrm{~cm}$ depth at two specific habitats, Phragmites-dominated riparian area (hereafter 'riparian') and main-channel area (hereafter 'in-stream'). To estimate the vegetation coverage, sites were ranked on a $0-1$ scale with 0 when no macrophytes were present and 1 with $100 \%$ coverage within a $100 \mathrm{~m}^{2}$ area. The sediment types were also ranked on a 1-2 scale with 1 for sandy sediments and 2 for gravelly sediments (Udy et al., 2006).

Sediment temperature (Temp.) was determined on site using a portable thermometer. Sediment water content (WC), organic matter content (SOM), extractable nitrate $\left(\mathrm{NO}_{3}{ }^{-} \mathrm{N}\right)$, extractable ammonium $\left(\mathrm{NH}_{4}{ }^{+}-\mathrm{N}\right)$ and dissolved organic carbon (DOC) were determined by standard methods (Page, 1982). Measurement of the activities of extracellular enzymes in sediments related to organic matter decomposition and mineralization of $\mathrm{N}$-related organic compounds ( $\beta$-glucosidase [BG] and N-acetylglucosaminidase [NAG], respectively) were employed as described in (Kang et al., 1998).

\section{Quantitative PCR assay}

The DNA of sediment samples was extracted from $1 \mathrm{~g}$ of sediment using the UltraClean Soil DNA Kit (MoBio Laboratories). Quantitative PCR (q-PCR) reaction was carried out with an I-Cycler ${ }^{\mathrm{TM}}$ (Version 3.0a, Bio-Rad, USA) by using SYBR Green as the detection system in a reaction mixture of $20 \mu \mathrm{l}$ containing $0.5 \mu \mathrm{M}$ (of each) primer, $10 \mu \mathrm{l}$ of SYBR Green Supermix, $2 \mu$ of ten-times diluted DNA template $(\sim 100$ ng of DNA template), and RNase-free water to a total volume of $20 \mu 1$. Thermal cycling conditions for the nirS gene included 40 cycles with denaturation at $95^{\circ} \mathrm{C}$ for $30 \mathrm{sec}$, primer annealing at $65^{\circ} \mathrm{C}$ for $45 \mathrm{sec}$ and extension at $72^{\circ} \mathrm{C}$ for $30 \mathrm{sec}$; for nirK gene included 40 cycles at $95^{\circ} \mathrm{C}$ for $15 \mathrm{sec}$, primer annealing at $63^{\circ} \mathrm{C}$ for $30 \mathrm{sec}$ and extension at $72^{\circ} \mathrm{C}$ for $30 \mathrm{sec}$; for $n o s Z$ gene included 50 cycles with denaturation at $94^{\circ} \mathrm{C}$ for $25 \mathrm{sec}$, primer annealing at $56^{\circ} \mathrm{C}$ for $25 \mathrm{sec}$, and extension at $72^{\circ} \mathrm{C}$ for $25 \mathrm{sec}$. nirs q-PCR was performed with the nirS832F (5'-TAC CAC CCC GAG CCG CGC GT-3') and nirS3R (5'-GCC GCC GTC RTG VAG GAA-3') primers, as described by Liu et al. (2003) and Braker et al. (1998). nirK q-PCR was performed with the nirK876F (ATY GGC GGV AYG GCG A) and nirK1040R (GCC TCG ATC AGR TTR TGG TT) primers (Henry et al., 2004). nosZ q-PCR was performed with the nosZF1181 (5'-CG (C/T)TGTTC(A/C/G/T)TCGACAGCCAG-3') and nosZR1880 (5'-CATGTGCAG(A/C/G/T)GC(A/G)TGGCAGA-3') primers (Rich et al., 2003). Two independent quantitative PCRs were performed on each DNA extract. The standard curves were created using 10 -fold dilution series of plasmid DNA containing the nirS or nos $Z$ gene. The potential presence of PCR inhibitors in sediment DNA extracts was tested by running a real-time PCR assay on serial dilution of sediment DNA extracts. No inhibition was detected in any case. The PCR efficiency was estimated as described by Bustin et al. (2009). The q-PCR efficiency values for nirS and nosZ were 0.970 and 0.945 , respectively. The q-PCR efficiency for the nirK was not checked as the nirK could not be detected in all the sediment samples.

\section{Denitrification enzyme activity}

Denitrification enzyme activities (DEAs) were determined for sediment samples using the acetylene block technique, which inhibits the final conversion of $\mathrm{N}_{2} \mathrm{O}$ to $\mathrm{N}_{2}$ gas (Smith and Tiedje, 1979). Forty grams of samples of homogenized fresh sediments were placed in 600-ml bottles. The samples were amended with $80 \mathrm{~mL}$ solution containing a high concentration of nitrate and glucose $\left(62.4 \mathrm{mg} \mathrm{NO}{ }_{3}^{-} \mathrm{N} / \mathrm{L}\right.$ as $\mathrm{KNO}_{3}, 100 \mathrm{mg}$ dextrose/L and $10 \mathrm{mg}$ chloramphenicol/L). Bottles were flushed for $30 \mathrm{~min}$ with oxygen-free nitrogen gas to ensure an anaerobic condition, and acetone-free acetylene gas was added to each bottle to achieve a final concentration of $10 \%(10 \mathrm{kPa})$ in the gas phase. The bottles were then incubated at $20^{\circ} \mathrm{C}$ in a horizontal shaker for $30 \mathrm{~min}$, before sampling the headspace and analyzing for $\mathrm{N}_{2} \mathrm{O}$ by ECD-equipped gas chromatography. 5-ml gas samples were taken every hour to get five data points and calculate the slope of the line (denitrification enzyme activity, $\mu \mathrm{g} \mathrm{N}_{2} \mathrm{O} \mathrm{g}{ }^{-1}$ dry sediment $\mathrm{h}^{-1}$ ) relating time to $\mathrm{N}_{2} \mathrm{O}$ headspace concentrations. To correct for the liquid-gas equilibrium in this assay, Bunsen coefficient at $20^{\circ} \mathrm{C}(\mathrm{b}=$ 0.632 ) were used to calculate the amount of $\mathrm{N}_{2} \mathrm{O}$ dissolved in the solution from the $\mathrm{N}_{2} \mathrm{O}$ concentration in the gas phase (Groffman et al., 1999).

\section{Statistical analysis}

Repeated-measures ANOVA analysis (by SPSS Statistics 
21.0) was used to analyze differences in biological and physicochemical properties of soils for each streambed feature (sandy or gravelly). The variations between Site (dam-affected sites vs. reference sites), Habitat (in-stream vs. riparian), Time and the interaction effects for each streambed feature were analyzed for all the parameters. All non-normal distributed data, determined with Kolmogorov-Smirnov test, (i.e., SOM, $\mathrm{NO}_{3}{ }^{-}-\mathrm{N}, \mathrm{NH}_{4}{ }^{+}-\mathrm{N}, \mathrm{NAG}, \mathrm{BG}$, nirS and nos $\mathrm{Z}$ gene copy number, nirs: nosZ and DEA) were Log transformed prior to ANOVA analysis. Some measured DEAs were below the detection limit and therefore were set equal to 0. DEA data were thus $\log 10$ $(\mathrm{DEA}+1)$ transformed.

Canonical correspondence analysis (CCA), a multivariate method, has been widely used to explore relationships between environmental factors and microbial populations (Lepš and Šmilauer, 2003). Canoco for Windows 4.5 (Center for Biometry, The Netherlands) was used for CCA. The Monte Carlo permutation test was used to test the significance of the correlations between microbial community gene abundances and measured environmental variables.

\section{Results}

\section{Hydrological conditions}

The dam-affected sites $\left(S_{1}\right.$ and $\left.S_{2}\right)$ were hydrologically different compared to the reference sites $\left(R_{1}\right.$ and $\left.R_{2}\right)$, especially during the annual flooding period from July to September (Fig. 2). During flooding period, the discharge patterns at the dam-affected sites were characterized by a higher frequency of flood peaks than those in the reference sites.

\section{Enzyme activities and physicochemical parameters}

The damming could cause considerable changes of water content and BG activities (for sandy sediments) and DOC and $\mathrm{NH}_{4}{ }^{+} \mathrm{N}$ concentrations (for gravelly sediments) (Table 1). However, the effects of damming on water content, BG
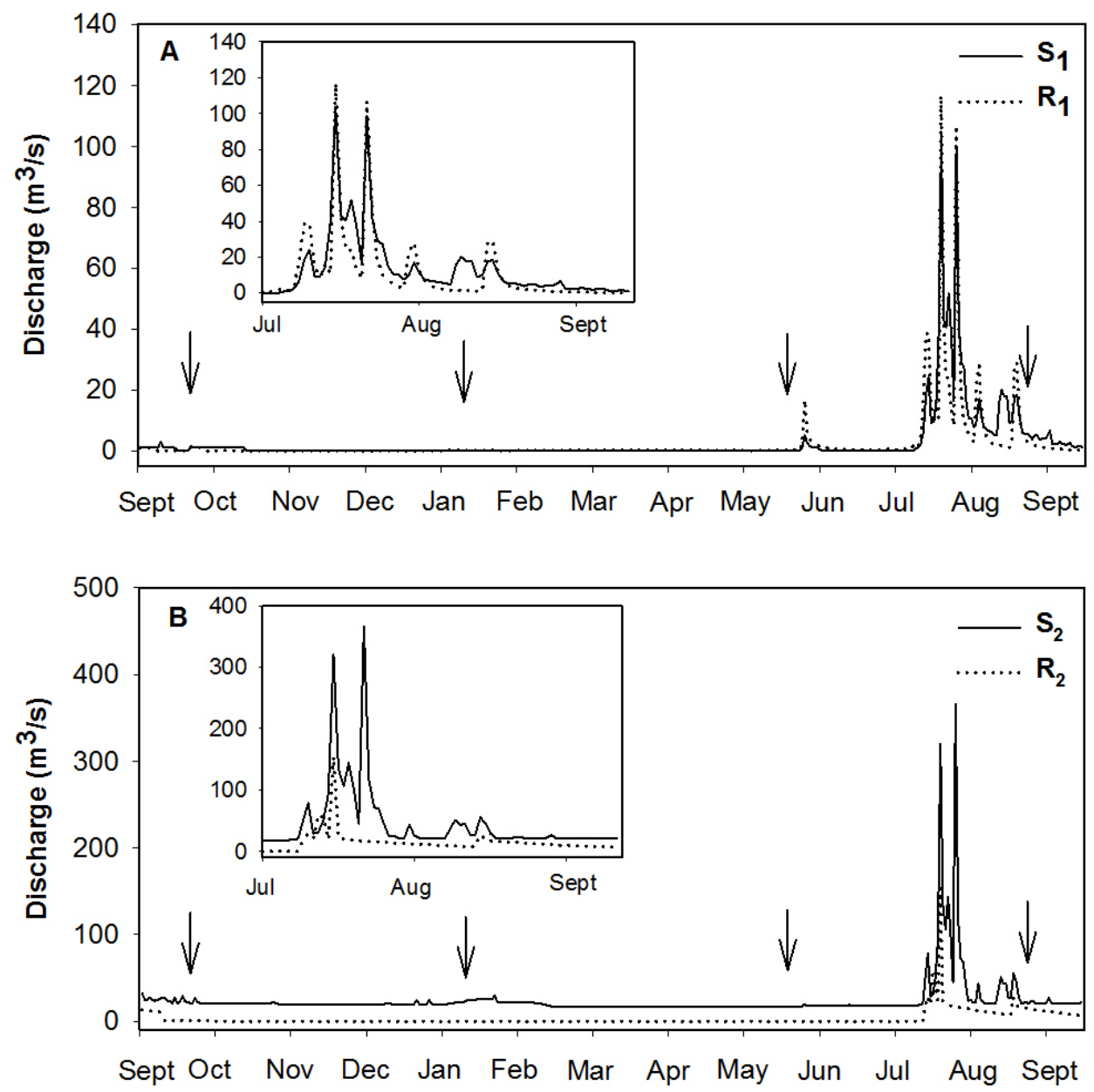

Fig. 2. Hydrographs for (A) gravelly sites and (B) sandy sites in the Nakdong River from September 2008 to September 2009. Discharges are presented as daily mean values. Arrows indicate the sampling times (Data source: Korea Ministry of Land, Infrastructure and Transport). 
142 Vo et al.

Table 1. Repeated measures ANOVA of biological and physicochemical parameters

\begin{tabular}{|c|c|c|c|c|c|c|c|c|c|c|c|}
\hline & Temp. & WC & DOC & $\mathrm{NH}_{4}^{+}-\mathrm{N}^{\dagger}$ & $\mathrm{NO}_{3}{ }^{-}-\mathrm{N}^{\dagger}$ & $\mathrm{BG}^{\dagger}$ & $\mathrm{NAG}^{\dagger}$ & $\mathrm{DEA}^{\dagger}$ & $\operatorname{nirS}^{\dagger}$ & $\operatorname{nos} Z^{\dagger}$ & nirS:nos $Z^{\dagger}$ \\
\hline \multicolumn{12}{|l|}{ Gravel } \\
\hline Site & ns & ns & $110.850^{* * * *}$ & $7.918^{*}$ & ns & ns & ns & ns & ns & ns & ns \\
\hline Habitat & ns & $248.338^{* * *}$ & $151.861^{* * *}$ & $63.401^{* * *}$ & ns & $21.912^{* * *}$ & $18.401^{*}$ & ns & $14.026^{*}$ & ns & ns \\
\hline Time & $2934.154^{* * * *}$ & ns & $25.109^{* * *}$ & $244.897^{* * * *}$ & $13.058^{* * *}$ & $39.524^{* * *}$ & $65.770^{* * * *}$ & $6.204^{*}$ & $69.583^{* * *}$ & $23.626^{* * * *}$ & $68.194^{* * * *}$ \\
\hline Site $\mathrm{x}$ Habitat & ns & $9.331^{*}$ & $107.834^{* * *}$ & $141.939^{* * * *}$ & $24.728^{* * *}$ & ns & ns & ns & $8.959^{*}$ & ns & ns \\
\hline Time $\mathrm{x}$ Site & ns & ns & $\mathrm{ns}$ & $8.264^{*}$ & ns & ns & ns & ns & ns & ns & ns \\
\hline Time $\mathrm{x}$ Habitat & ns & ns & ns & ns & ns & $17.990^{* * *}$ & ns & ns & $\mathrm{ns}$ & ns & $\mathrm{ns}$ \\
\hline Time $\mathrm{x}$ Site $\mathrm{x}$ Habitat & ns & ns & $\mathrm{ns}$ & $6.838^{*}$ & ns & ns & ns & ns & ns & ns & ns \\
\hline \multicolumn{12}{|l|}{ Sand } \\
\hline Site & ns & $51.453^{* *}$ & ns & ns & ns & $5.860^{*}$ & ns & ns & ns & ns & ns \\
\hline Habitat & ns & $1232.872^{* * *}$ & ns & ns & ns & $10.068^{*}$ & ns & ns & $41.772^{* *}$ & ns & $21.611^{*}$ \\
\hline Time & $1160.897^{* * * *}$ & $6.749^{*}$ & $24.793^{* *}$ & $203.039^{* * * *}$ & $144.776^{* * *}$ & ${ }^{*} 80.216$ *** & $1208.371^{* * * *}$ & ns & $39.646^{* * * *}$ & ns & $60.127^{* * *}$ \\
\hline Site $\mathrm{x}$ Habitat & ns & $22.175^{* *}$ & ns & $8.181^{*}$ & ns & $\mathrm{ns}$ & ns & $9.753^{*}$ & ns & ns & ns \\
\hline Time $\mathrm{x}$ Site & ns & $6.393^{*}$ & ns & ns & $7.373^{*}$ & ns & ns & ns & ns & ns & $14.423^{* *}$ \\
\hline Time $\mathrm{x}$ Habitat & ns & $7.761^{*}$ & ns & ns & $15.957^{* * *}$ & ns & ns & $\mathrm{ns}$ & $5.129^{*}$ & $5.133^{*}$ & $50.551^{* * * *}$ \\
\hline Time $\mathrm{x}$ Site $\mathrm{x}$ Habitat & $\mathrm{ns}$ & $6.707^{*}$ & ns & $9.385^{*}$ & $6.714^{*}$ & ns & $9.769^{*}$ & $9.722^{* *}$ & ns & ns & $28.700^{* *}$ \\
\hline
\end{tabular}

Significance level at ${ }^{*} P<0.05,{ }^{* *} P<0.01,{ }^{* * *} P<0.001$

ns: not significant

${ }^{\dagger}$ Transformed data

activities, DOC and $\mathrm{NH}_{4}{ }^{+} \mathrm{N}$ concentrations also varied significantly across the habitats and/or sampling times (Table 1). Water contents in in-stream sediments remained similarly among different sites and over time with the mean value of $21 \%$. In riparian areas, water contents in January 2009 and May 2009 were lower than those in September 2008 and August 2009 except for gravelly sediments downstream of dams (Figs. $3 \mathrm{~A}$ and $3 \mathrm{~B}$ ). Water contents in riparian sediments in different sites were also distinct. For gravelly sediments, compared to references, water contents in riparian sediments downstream of dams increased in January 2009 and May 2009 but likely remained similarly in September 2008 and August 2009 (Fig. $3 \mathrm{~A}$ ). For sandy sediments, compared to references, water contents in riparian sediments downstream of dams decreased except for those in September 2008 (Fig. 3B).

DOC concentrations in September 2008 and January 2009 were higher than those in May and August 2009 (Figs. 3C and 3D). For gravelly sediments, DOC concentrations downstream of dams mostly increased compared to references except for slight decreases in in-stream areas observed in September 2008 and August 2009 (Fig. 3C). DOC concentrations in gravelly sediments reached the highest value in riparian areas downstream of dams (up to $47.5 \mathrm{mg} / \mathrm{g}$ dry soil in January 2009; Fig. 3C). For sandy sediments, increases of DOC concentrations downstream of dams observed in riparian areas in September 2008 and January 2009 and in in-stream areas in May 2009, even weakly, were corroborated (Fig. 3D).
$\mathrm{NH}_{4}{ }^{+} \mathrm{N}$ concentrations reached the highest values in May 2009 (up to $48.6 \mathrm{mg} / \mathrm{g}$ dry soil in gravelly areas and $66.2 \mathrm{mg} / \mathrm{g}$ dry soil in sandy areas; Figs. $3 \mathrm{E}$ and $3 \mathrm{~F}$ ). The variation of $\mathrm{NH}_{4}{ }^{+} \mathrm{N}$ concentrations among different sites were observed only in May 2009 and January 2009. Specifically, $\mathrm{NH}_{4}{ }^{+}-\mathrm{N}$ concentrations increased in riparian sediments but decreased in in-stream sediments downstream of dams in comparison to references (Figs. 3E and 3F). $\mathrm{NO}_{3}{ }^{-}-\mathrm{N}$ concentrations showed contrasting temporal patterns compared to $\mathrm{NH}_{4}{ }^{+}-\mathrm{N}$ concentrations. $\mathrm{NO}_{3}{ }^{-} \mathrm{N}$ concentrations were lowest in May 2009 (Figs. 3G and 3H). For gravelly sediments, compared to references, $\mathrm{NO}_{3}{ }^{-}-\mathrm{N}$ concentrations increased in riparian areas but decreased in in-stream areas downstream of dams (Fig. $3 \mathrm{G})$. For sandy sediments, the increase of $\mathrm{NO}_{3}{ }^{-} \mathrm{N}$ concentrations downstream of dams observed in riparian areas in September 2008 was corroborated. In in-stream areas, however, $\mathrm{NO}_{3}{ }^{-} \mathrm{N}$ concentrations in sandy sediments downstream of dams increased, compared to references, especially in September 2008 and August 2009 (Fig. 3H). This contrasts with the pattern observed in in-stream areas dominated with gravelly sediments.

BG and NAG activities were highest in September 2008 (Fig. 4). For gravelly sediments, BG and NAG activities were higher in riparian areas than those in in-stream areas (Figs. 4A and 4C). For sandy sediments, however, BG and NAG activities were slightly lower in riparian areas than those in in-stream areas (Figs. 4B and 4D). For all sediment types and 
habitats, mean temperatures were highest in September 2008 or August $2009\left(24.0^{-} 24.9^{\circ} \mathrm{C}\right)$ and lowest in January 2009 (3.3-
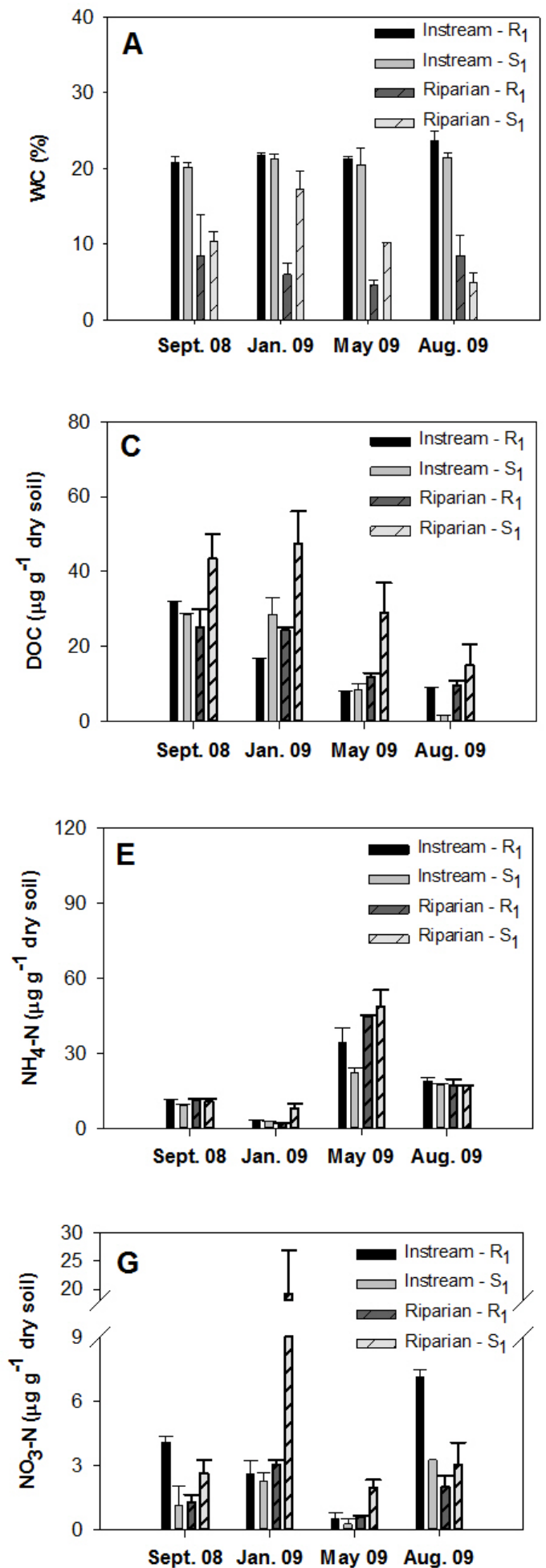

$\left.4.3^{\circ} \mathrm{C}\right)$.

DEAs were not significantly different in downstream areas
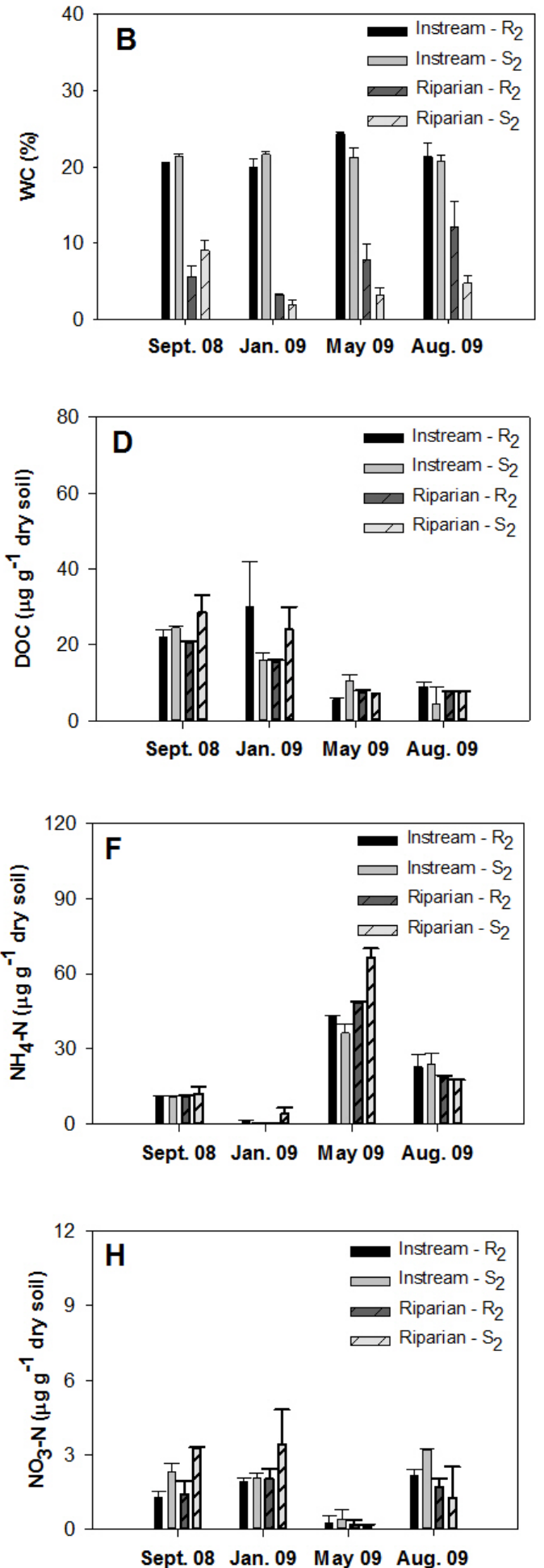

Fig. 3. Temporal patterns (Mean+SE) of (A-B) WC, (C-D) DOC concentrations, (E-F) $\mathrm{NH}_{4}{ }^{+}-\mathrm{N}$ concentrations, and $(\mathrm{G}-\mathrm{H}) \mathrm{NO}{ }_{3}{ }^{-}-\mathrm{N}$ concentrations in different habitats patched in gravelly $\left(R_{1}\right.$ and $\left.S_{1}\right)$ and sandy $\left(R_{2}\right.$ and $\left.S_{2}\right)$ streams. 
of dams and references (Table 1). However, in May 2009 and August 2009, DEAs downstream of dams were considerably higher, specifically in riparian areas with gravelly sediments and in-stream areas with sandy sediments, than those in references (Figs. 5A and 5B). The highest DEAs were mostly observed in May 2009 in in-stream sediments downstream of dams (233.9 $\mathrm{mg} \mathrm{N} \mathrm{N}_{2} \mathrm{O} / \mathrm{g}$ dry soil/h in gravelly areas and 604.4 $\mathrm{mg} \mathrm{N}_{2} \mathrm{O} / \mathrm{g}$ dry soil/h in sandy areas; Figs. 5A and 5B).

\section{Denitrifier abundances}

nirK was not amplified in all sediment samples. nirS-harboring denitrifiers were much more abundant than nosZ-harboring denitrifiers in all sediments, from two to four orders of magnitude difference (Figs. 5C-5F). Copy numbers of nirS and nos $Z$ as well as nirS:nos $Z$ ratios were not significantly different downstream of dams compared to references (Table 1). Significant difference among the habitats of nirS gene copy numbers (in both sediment types) and nirS:nosZ ratios (only in sandy sediments) were observed (Table 1). The numbers of nirS gene copies in in-stream sediments were mostly higher than those in riparian sediments $(\sim 1.5-3.5$ times in references and $~ 1.5-5.2$ times in downstream areas of dams; Figs. 5C and 5D). For gravelly sediments, compared to references, nirS gene copy numbers downstream of dams decreased in in-stream areas (except for those in May 2009) but slightly increased in riparian areas (Fig. 5C). nos $Z$ gene copy numbers showed similar patterns across the sites, but with different magnitudes of discrepancy. For sandy sediments, compared to references, nirS gene copy numbers downstream of dams increased in both in-stream area and riparian area (except for those in riparian areas in May 2009) (Fig. 5D). Compared to references, nos $Z$ gene copy numbers downstream of dams also increased in in-stream areas and riparian areas with sandy sediments (except for those in riparian areas in May 2009). Downstream of dams, most abundance of nirS and nosZ-harboring denitrifiers in sediments reached to more than $5.1 \times 10^{8}$ and $4.7 \times 10^{4}$ copies/g dry soil, respectively (Figs. 5C$5 \mathrm{~F})$.

nirS: $n o s Z$ ratios were not significantly different across the sites with gravelly sediments (Table 1). For sandy sediments of references, nirS: nosZ ratios in in-stream areas were mostly higher than those in riparian areas. However, for sandy sediments downstream of dams, a contrasting pattern of nirS: nos $Z$ ratios across different habitats were observed except for those in January 2009 (Fig. 5H). We also observed significant temporal variations in nirS gene copy numbers and nirS: nosZ ratios (for both sediment types) and nos $Z$ gene copy numbers (only in gravelly sediments). The most abundance of
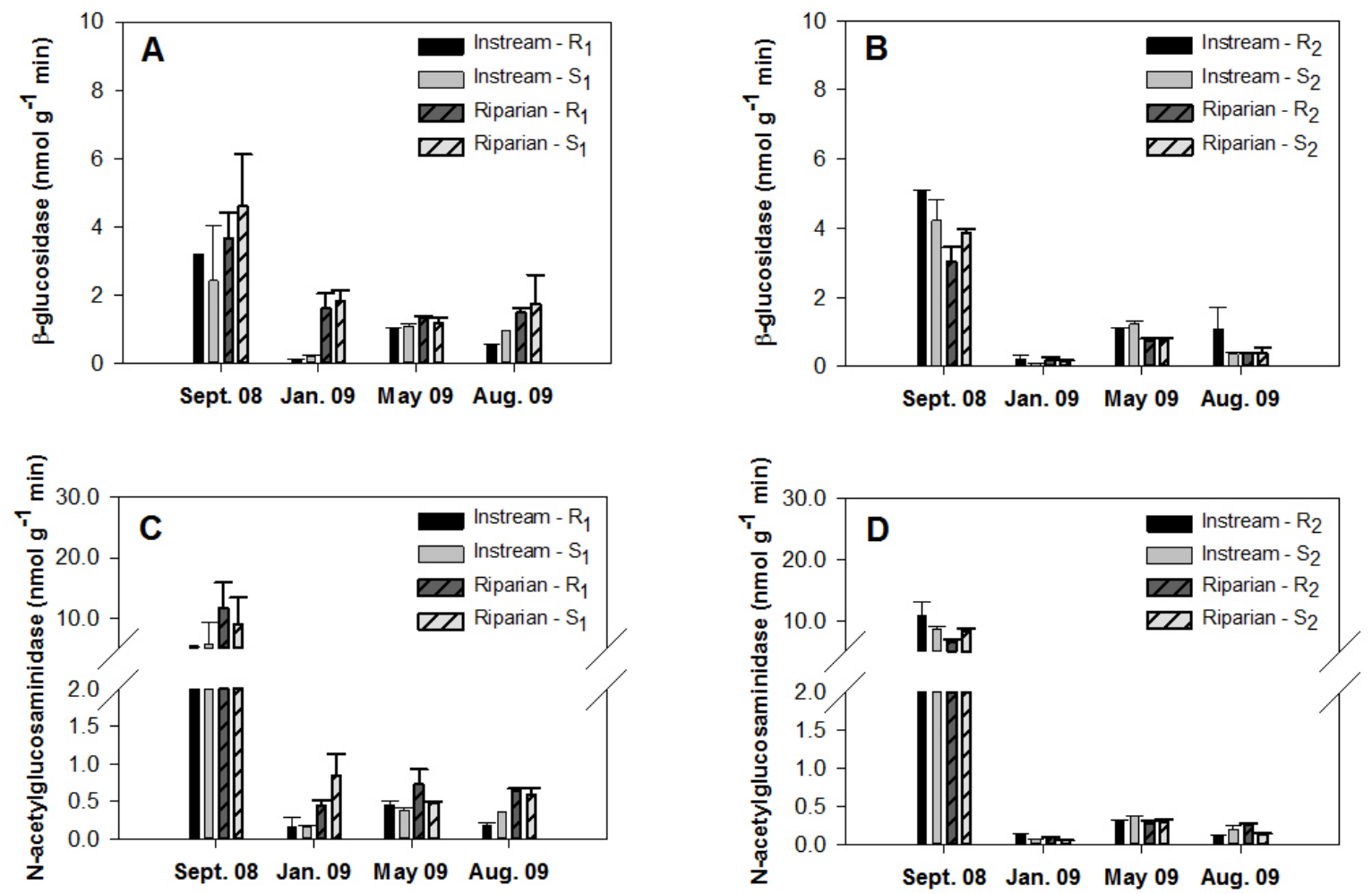

Fig. 4. Temporal patterns (mean $+\mathrm{SE})$ of $(\mathrm{A}-\mathrm{B}) \mathrm{BG}$ activities and $(\mathrm{C}-\mathrm{D}) \mathrm{NAG}$ activities in different habitats patched in gravelly $\left(\mathrm{R}_{1}\right.$ and $\left.\mathrm{S}_{1}\right)$ and sandy $\left(\mathrm{R}_{2}\right.$ and $\left.\mathrm{S}_{2}\right)$ streams. 
nirS-harboring denitrifiers was observed in May 2009 and August 2009, whereas most abundance of nosZ-harboring
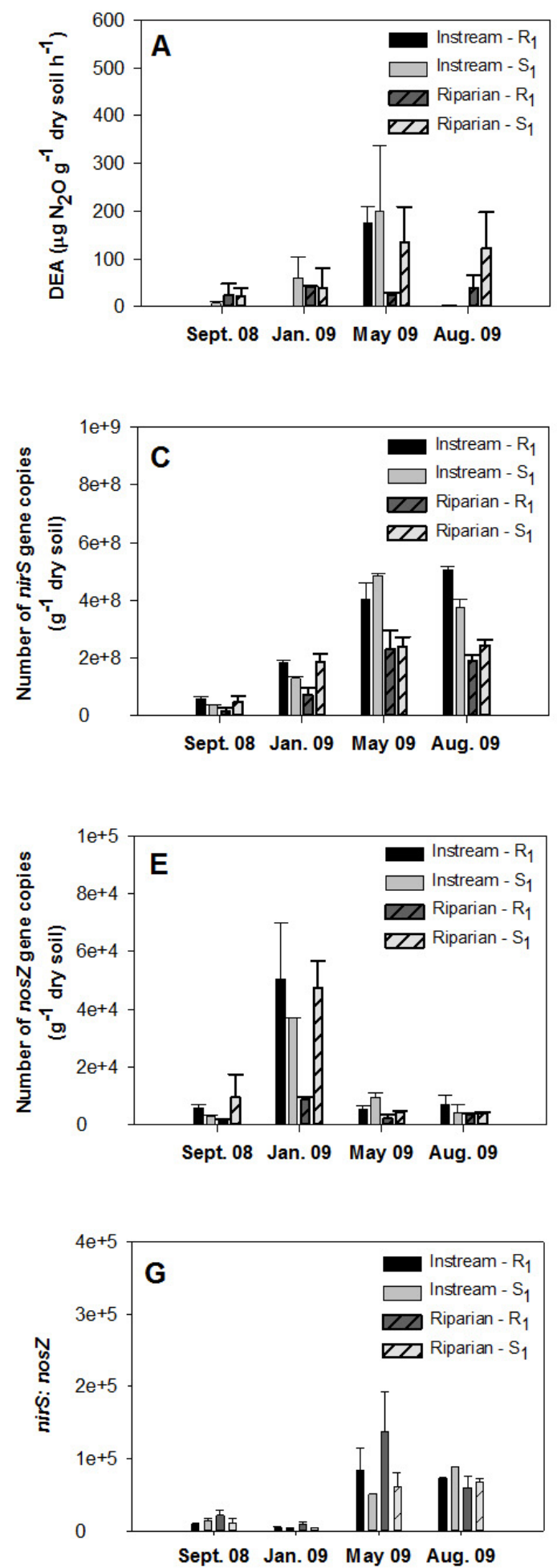

denitrifiers was observed in January 2009 with exceptions in sandy sediments (Figs. 5C-5F).
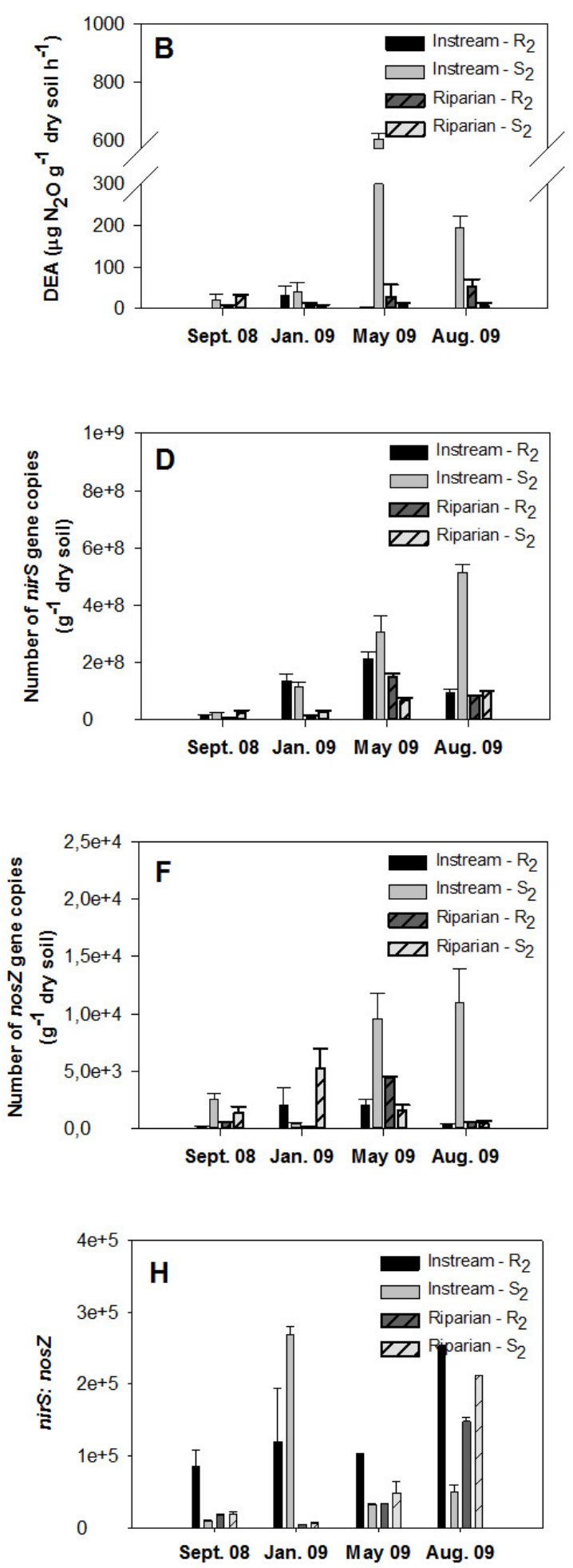

Fig. 5. Temporal patterns (mean + SE) of (A-B) DEA, (C-D) nirS gene copy numbers, (E-F) nosZ gene copy numbers, and (G-H) nirS:nosZ ratios in different habitats patched in gravelly $\left(\mathrm{R}_{1}\right.$ and $\left.\mathrm{S}_{1}\right)$ and sandy $\left(\mathrm{R}_{2}\right.$ and $\left.\mathrm{S}_{2}\right)$ streams. 


\section{Canonical correspondence analysis}

The first two canonical axes of the CCA, when the sediment type and macrophyte presence were included as covariables, explained $24.9 \%$ of the variance in the gene abundance data and $100 \%$ of the variance in the total gene abundance-environment parameter relationship $(\mathrm{P}=0.066)$ (Fig. 6). The CCA analysis showed that none of the first two canonical axes represented the distribution of nirS genes. The first canonical axis, which explained $73.6 \%$ of the total gene abundance-environmental parameter variation and represented the distribution of nirS: nos $\mathrm{Z}$ ratios, was dominated mainly by $\mathrm{NH}_{4}{ }^{+} \mathrm{N}$ concentrations (0.26) and NAG activities (-0.15). The second canonical axis, which explained an additional $26.4 \%$ of the total gene abundance-environmental parameter variation and represented the distribution of $\operatorname{nos} Z$ gene, was dominated by DOC concentrations (0.50), temperature $(-0.45)$ and $\mathrm{NO}_{3}{ }^{-} \mathrm{N}$ concentrations $(0.34)$ as well as by $\mathrm{NH}_{4}{ }^{+}-\mathrm{N}$ concentrations (-0.34). The densities of nos $Z$ gene and the ratios between the densities of nirS and nos $Z$ gene in sediments were not different across the sites (downstream of dams vs. reference) in September 2008 and January 2009, but weakly separated in May 2009 and August 2009 mainly along the first axis (Fig. 6). DEA was correlated with the first axis $(0.35)$ in the direction for samples downstream of dams in May 2009 and August 2009. Samples were distinctly grouped according to the sampling times along the second axis (Fig. 6). Samples in May

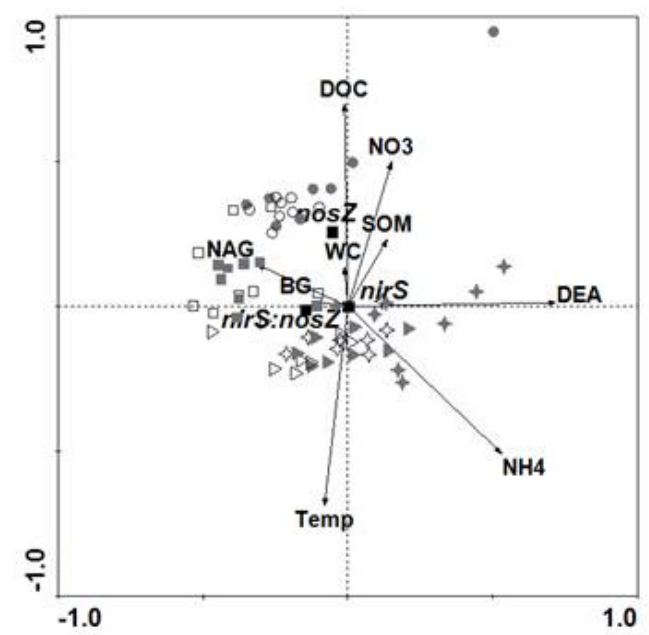

Fig. 6. Canonical correspondence analysis (CCA) of the nirS and nos $Z$ gene abundances, and nirS: nos $Z$ ratios (plotted as triangles) in relation to sediment environmental variables (plotted as vectors) for samples (plotted as squares for September 2008, dots for January 2009, stars for May 2009, and triangles for August 2009; open symbols represent samples in reference sites and closed symbols represent samples downstream of dams). The first (x axis) and second (y axis) canonical axes explain $73.6 \%$ and $26.4 \%$ of the gene abundance-environmental variable variance in the data, respectively.
2009 and August 2009 were arranged in the same direction of temperature effects. When the sampling time was included as a covariable, the CCA rendered the weaker relationship ( $\mathrm{P}=$ 0.106 ) between the axes, which respectively explained $87.1 \%$ and $12.9 \%$ of the gene abundance-environmental variable variance in the data (data not shown).

\section{Discussions}

For the past 30 years, damming of the streams has influenced the regime of downstream flows by increasing the frequencies of flood peaks. As such, we expected changes in the environmental conditions and an according degree of the variation of denitrification processes in downstream areas of dams. However, we found that abundances of nirS- and nosZ-harboring denitrifiers and denitrification enzyme activities did not significantly increase in downstream areas of dams. The spatial and temporal mismatch of the availabilities of nutrients (DOC and $\mathrm{NH}_{4}{ }^{+}-\mathrm{N}$ ) could constrain denitrifying activities in sediments downstream of dams. During a year period, DOC and $\mathrm{NH}_{4}{ }^{+}-\mathrm{N}$ concentrations significantly increased in the riparian sediments, but not in the in-stream sediments downstream of dams. Moreover, the temporal patterns of DOC and $\mathrm{NH}_{4}{ }^{+} \mathrm{N}$ concentrations were different with regard to hydrological events. In addition, the failure to detect a significant effect could be due to insufficient numbers of samples and study sites (as type II errors caused by insufficient power). Effects of small scale heterogeneity occur in sediments, especially when analyzing microbial populations, can be minimized by increasing the sampling effort.

The expansion of riparian vegetation downstream of dams could provide increasing amounts of terrestrial plant litters, thus organic substrates for microbial growth in the sediments downstream of dams (Frossard, 2011; Cho et al., 2012). The subsequent mineralization of these extra organic sources would then release sufficient amounts of inorganic $\mathrm{N}\left(\mathrm{NH}_{4}{ }^{+}\right.$and $\left.\mathrm{NO}_{3}{ }^{-}\right)$ and available $\mathrm{C}$ (DOC) for the successional dynamics of denitrifier commutnities. The close relation of $\mathrm{NH}_{4}{ }^{+}$ concentrations and denitrification potential rates suggests a tight coupling between nitrification and denitrification in sediments downstream of dams (Jenkins and Kemp, 1984; Maingi and Marsh, 2002; McClain et al., 2003; Seitzinger et al., 2006). Alternatively, the discrepancies between dynamics observed in the $\mathrm{NH}_{4}{ }^{+}-\mathrm{N}$ and $\mathrm{NO}_{3}{ }^{-} \mathrm{N}$ (or DOC) might imply further influence from the hydrological regime.

The significant decrease of $\mathrm{NH}_{4}{ }^{+} \mathrm{N}$ concentrations concurrent with an increase in $\mathrm{NO}_{3}{ }^{-}$concentrations after the 2009 flooding suggested a substantial effect of the hydrological event in availability of $\mathrm{O}_{2}$ in sediments. In addition, the 
temporal patterns of $\mathrm{NO}_{3}{ }^{-} \mathrm{N}$ were comparable with DOC patterns. In September 2008, one and a half months after the 2008 flooding, DOC concentrations in all sediments reached the highest value. BG and NAG activities also reached the highest ones at that time. It is well known that flooding water carry substantial quantities of sediment to downstream areas and this happen more intensively downstream from dams, as greater sediment accumulation would be expected in dam reservoirs (Wohl and Cenderelli, 2000). Large sedimentation rates downstream of dams thus can contribute to increased denitrification potential rates by fertilizing with organic carbon substrates and additional $\mathrm{NO}_{3}{ }^{-}$(Solomon et al., 2009).

In agricultural rivers, such as the Nakdong River, denitrification can be supported by the riverine $\mathrm{N}$ sources associated with livestock wastes or fertilizer loss. Especially, $\mathrm{NO}_{3}{ }^{-}$sources from adjacent agricultural lands enter the river (through direct discharge or soil-groundwater) could contribute substantially to the spatial-temporal variation of denitrification in rivers (Chen et al., 2014). During the flooding period, runoff and direct discharge carry more available $\mathrm{NO}_{3}{ }^{-}$and carbon sources to downstream in natural streams, but this is restrained with dam presence. Significant higher $\mathrm{NO}_{3}{ }^{-}$concentrations in gravelly sediments of references compared to downstream areas of dams were observed in September 2008 or August 2009. Hydrological regulation at dams also had a significant impact on the downstream hydrology in riparian areas (i.e., elevated levels of near-stream water table and increased stream inputs to the riparian zone) and $\mathrm{NO}_{3}^{-}$(removal) patterns in shallow groundwater (i.e., elevated subsurface inputs of nitrate and enhanced potential denitrification) (Leach, 2009). A combination of hydrologic connection and morphological characteristics as the main driver of sediment quality and microbial processes, particularly denitrification in floodplain sediments, was excellently discussed by Welti et al. (2012). The significant increase of $\mathrm{NO}_{3}{ }^{-}$concentrations in January 2009 in gravelly sediments of riparian areas downstream of dams compared to references suggests the effect of dams on the transport of nutrients from the upland to riparian zone and/or main channel. The present study cannot measure riverine $\mathrm{N}$ sources or groundwater pathways and its interaction with surface hydrological regime to distinguish the confounding effect or to provide further evidence of the coupling occurrence of hydrologic shifts (or hydrological connectivity) and denitrification potential. Conducting a randomized study of a sufficiently large sample taken as a whole can also help to minimize the effects of confounding factors. However, we believe that the dam itself can play central roles in the control of overall delivery and cycling of nutrients in rivers (Stanley and Doyle, 2002; Gergel et al., 2005). Thus, current results could assess the cascade effect of dams on the delivery and cycling of nitrogen in rivers, particularly via denitrification pathway.

We postulated that the sizes of denitrifier communities would vary according to differences in the magnitudes of the measured inorganic $\mathrm{N}$ and available $\mathrm{C}$ in sediments. In our study, we found that the abundances of nos $Z$ gene copies mirrored DOC and $\mathrm{NO}_{3}{ }^{-}$concentrations while the abundances of nirS gene copies reflected water contents and, to less extent, $\mathrm{NH}_{4}{ }^{+}$concentrations of sediments. The more abundances of nos $Z$ gene copies over time in sediments downstream of dams containing higher DOC concentrations were expected because readily available $\mathrm{C}$ can stimulate denitrification (Luo et al., 1999; Findlay et al., 2011). By using qPCR to quantify nosZ gene copies, Hallin et al. (2009) found nearly one order of magnitude more nos $Z$ gene copies in soils receiving organic fertilizer (solid cattle manure and sewage sludge) compared to the soil receiving only ammonium sulfate. Complex interactions between temperature, water content, $\mathrm{O}_{2}$ content, availability of $\mathrm{C}$ and $\mathrm{NO}_{3}^{-}$are known to be environmental factors that affect microbiological denitrification in stream sediments (McClain et al., 2003; Findlay et al., 2011). In our study, the abundances of nirS gene copies seem to link more to the variation of water contents as lower abundances of nirS gene copies were consistently observed in riparian sediments compared to in-stream sediments. Water content has been recognized as one of the most important regulator factors controlling denitrification in sediments (McClain et al., 2003).

NirK was not amplified in all samples in which nirS was detected. Thus, the nirS: nosZ ratio can be used to estimate the $\mathrm{N}_{2} \mathrm{O}$ emission potential of sediments (Philippot et al., 2011). Lower nirS: nosZ ratios, as mostly observed in gravelly riparian sediments downstream of dams, indicated the higher potential for complete denitrification compared to relevant reference sediments. The skew in the detection of nir types may be due to primer bias, as unique nirK sequences in aquatic sediments cannot be detected (Ellis et al., 2007). However, despite the potential influence of primer selection, there is a 'habitat filtering' effect on denitrifier communities with different nir types (Jones et al., 2008). Jones and Hallin (2010) have shown that the current global nirS dataset is dominated by representatives from aquatic environments, whereas soil denitrifiers dominate the nirK dataset.

In this study, the spatial gradients downstream from dams cover a chronosequence of approximately 30 years of soil development after the dam constructions. We postulated that the increase of abundances of nos $Z$ and nirS-harboring denitrifier communities in sediments of considered habitats downstream of dams, weakly but consistently over time, would 
present the initial responses of functional communities based on the physiological adaptation. However, the densities of different denitrification genes in stream sediments would also vary either following the distinctive trends or with different rates after the dam construction, a representative of anthropogenic disruption (sensu Kandeler et al., 2006; Attard et al., 2011). There, they showed that densities of nosZ-harboring denitrifier communities increased, while densities of nirK and nirS-harboring denitrifier communities did not, along a progressing succession of soils in a receding glacier foreland or under land-use changes. In this study, the CCA analysis showed that abundances of nosZ-harboring denitrifier communities, but not of nirK- and nirS-harboring denitrifier communities, weakly correlated to $\mathrm{NH}_{4}{ }^{+}, \mathrm{NO}_{3}{ }^{-}$, and DOC concentrations and to denitrification enzyme activities. Temperature and hydrological regime substantially influence the relationship between denitrifier gene abundances and nutrient availabilities and denitrification potential rates. The weak relationship between nos $Z$ gene abundances and nutrient availabilities is in agreement with Kong et al. (2010). Other studies have also found that differences in denitrifier community compositions and abundances in wetland and agricultural soils were not related to denitrification rates and $\mathrm{N}_{2} \mathrm{O}$ emissions (Dandie et al., 2008; Ma et al., 2008). Gene abundance is not necessarily to be correlated with potential activity, which reflects the readily activated enzymes, because the genetic pool only partly contributes to the activity at a given time point (Enwall et al., 2010).

The approach used in this study had been widely applied in microbial ecology to quantify the abundance of functional gene markers within the environment and to relate variation in genetic potential with variation in abiotic or biotic factors, biological activities and process rates. However, as in any PCR-based study, the use of specific primers may not allow the quantification of entire denitrifying communities. PCR-based approaches require the prior sequence data of the specific target gene of interest. Consequently, q-PCR can only be used for targeting of known genes and is inevitably limited to access the 'unknown' genes (Smith and Osborn, 2009; Verbaendert et al., 2011). Because the majority of microorganisms in the environment are highly divergent from those of most cultured organisms, the employment of emerging "omics" approaches along with advanced analytical chemistry provides new opportunities to bridge the knowledge gap across scales and to link microbial functions with biogeochemical cycles (Lin et al., 2014). Recently, several metagenomic studies could provide insights into changes of genes associated with metabolic potentials for $\mathrm{C}$ and $\mathrm{N}$ cycling in response to environmental change (Mackelprang et al., 2011; Fierer et al., 2012). A more comprehensive and complete inventory of microbial genes in soils or sediments is desired by taking advantage of pyrosequencing technique in metagenomic approach (Smith and Osborn, 2009; Myrold et al., 2013). Complementarily, metatranscriptomic approach can assess and strengthen the connections between the structure, or composition, of the microbial community with actual microbial activity (Myrold et al., 2013). However, the utility of soil metatranscriptomics has not yet been fully explored and current challenges in advancing metagenomics include the difficulty in adopting standard methods, data reduction and analysis, improvement in functional gene annotation and database curation (Myrold et al., 2013). Progress with further developments of metagenomic and metatranscriptomic methods promises to enhance our understanding about the response of active microorganisms to environmental change.

This study sought to relate the abundances of denitrifier communities to their potential activities along a hydro-geochemical gradient in downstream sediments after long-term hydrological managements with dams. We found that although upstream hydrological management with dams influenced the physicochemical properties of sediments (water content and available $\mathrm{C}$ and $\mathrm{N}$ contents), physicochemical changes in sediments did not relate to variations in abundances of nirS and nosZ-carrying denitrifier communities and denitrification potential rates. Either primer bias or habitat-filtering effect could account for the absence of nirK gene in the stream sediments. Seasonality, particularly the variation of temperature and hydrology regime, substantially influenced the relationship between denitrifier abundances and activities and environmental parameters.

\section{적요}

댐의 존재가 하천 생태계에 미치는 영향을 연구하기 위해 다 양한 연구가 지금까지 수행되어 왔지만, 댐이 하류의 탈질화에 미치는 영향은 잘 알려져 있지 않다. 대한민국 낙동강의 댐 원류 에서 탈질화 효소 활성도(잠재 탈질율)와 탈질균 분포(nirS, $n i r K, n o s Z$ 유전자를 표지유전자로 사용)를 조사하였다. 자갈 혹 은 모래로 채워진 하천의, 갈대가 우거진 하변지역과 강바닥의 침전물을 채취하여 조사하였다. 이 실험의 가설은 다음과 같다. (i) 하천 침전물의 $\mathrm{N}$ 과 $\mathrm{C}$ 의 사용유효량이 높을수록 대조군에 비 해 미생물 군집의 탈질화 작용이 더욱 증진한다, (ii) 하천생태계 마다 상이하게 나타나는 잠재 탈질율 간의 차이는 탈질 미생물 의 양에 비례한다. 30 여 년간 댐에 의해 수문학적으로 큰 차이가 있었고 또한 댐 하류의 저서에 무기질소와 용존유기탄소 농도가 대조군에 비해 매우 높았음에도 불구하고, 탈질균 군집의 양과 잠재 탈질율은 하천 간에 큰 차이가 없었다. 하지만 $n i r S$ 유전자 와 $n o s Z$ 유전자의 양과 잠재 탈질율은 댐 하류에 존재하는 자갈 
이 많은 하변과 모래가 많은 하천 바닥에서 홍수빈도와 계절별 온도변동에 관련하여 크게 증가함을 알 수 있었다. nirK 유전자 는 모든 시료에서 발견되지 않았다. Canonical correspondence analysis (CCA) 분석결과는 탈질균 군집 양과 영양염류 가용도 와 잠재 탈질율 사이에는 약한 상관관계가 있음을 보여주었다.

\section{Acknowledgements}

This study was supported by the Center for Aquatic Ecosystem Restoration (CAER) of the Ecostar project from the Ministry of Environment (MOE), Republic of Korea (MOE; EW33-08-11) and NRF (20110029802).

\section{References}

Attard, E., Recous, S., Chabbi, A., De Berranger, C., Guillaumaud, N., Labreuche, J., Philippot, L., Schmid, B., and Le Roux, X. 2011. Soil environmental conditions rather than denitrifier abundance and diversity drive potential denitrification after changes in land uses. Glob. Change Biol. 17, 1975-1989.

Boyer, E., Goodale, C., Jaworski, N., and Howarth, R. 2002. Anthropogenic nitrogen sources and relationships to riverine nitrogen export in the northeastern USA. Biogeochemistry 57, 137169.

Braker, G., Fesefeldt, A., and Witzel, K.P. 1998. Development of PCR primer systems for amplification of nitrite reductase genes (nirK and nirS) to detect denitrifying bacteria in environmental samples. Appl. Environ. Microbiol. 64, 3769-3775.

Burgin, A. and Hamilton, S. 2007. Have we overemphasized the role of denitrification in aquatic ecosystems? A review of nitrate removal pathways. Front. Ecol. Environ. 5, 89-96.

Burke, M., Jorde, K., and Buffington, J.M. 2009. Application of a hierarchical framework for assessing environmental impacts of dam operation: changes in streamflow, bed mobility and recruitment of riparian trees in a western North American river. J. Environ. Manage. 90, S224-S236.

Bustin, S.A., Benes, V., Garson, J.A., Hellemans, J., Huggett, J., Kuista, M., Mueller, R., and Nolan, T. 2009. The MIQE guidelines: Minimum information for publication of quantitative real-time PCR experiments. Clin. Chem. 55, 611-622.

Cao, Y.P., Green, P.G., and Holden, P.A. 2008. Microbial community composition and denitrifying enzyme activities in salt marsh sediments. Appl. Environ. Microbiol. 74, 7585-7595.

Chen, N., Wu, J., Chen, Z., Lu, T., and Wang, L. 2014. Spatial-temporal variation of dissolved $\mathrm{N}_{2}$ and denitrification in an agricultural river network, southeast China. Agricul. Ecosyst. Environ. 189, 1-10.

Cho, H.J., Jin, S.N., Cho, K.H., Woo, H.S., and Egger, G. 2012. Establishment and expansion of willows after dam operation in a monsoonal sandy stream. In Mader, H. and Kraml, J. (eds.). 9th International Symposium on Ecohydraulics. Vienna, Austria.

Choi, S.U.K., Yoon, B., and Woo, H. 2005. Effects of dam-induced flow regime change on downstream river morphology and vegetation cover in the Hwang River, Korea. River Res. Applications 21, 315325.

Chun, K.C., Chang, R.W., Williams, G.P., Chang, Y.S., Tomasko, D., LaGory, K., Ditmars, J., Chun, H.D., and Lee, B.K. 2001. Water quality issues in the Nakdong River Basin in the Republic of Korea. Environ. Engineer. Policy 2, 12.

Dandie, C.E., Burton, D.L., Zebarth, B.J., Henderson, S.L., Trevors, J.T., and Goyer, C. 2008. Changes in bacterial denitrifier community abundance over time in an agricultural field and their relationship with denitrification activity. Appl. Environ. Microbiol. 74, 59976005.

Dandie, C.E., Miller, M.N., Burton, D.L., Zebarth, B.J., Trevors, J.T., and Goyer, C. 2007. Nitric oxide reductase-targeted real-time PCR quantification of denitrifier populations in soil. Appl. Environ. Microbiol. 73, 4250-4258.

Dandie, C.E., Wertz, S., Leclair, C.L., Goyer, C., Burton, D.L., Patten, C.L., Zebarth, B.J., and Trevors, J.T. 2011. Abundance, diversity and functional gene expression of denitrifier communities in adjacent riparian and agricultural zones. FEMS Microbiol. Ecol. 77, 69-82.

Davidsson, T.E. and Stahl, M. 2000. The influence of organic carbon on nitrogen transformations in five wetland soils. Soil Sci. Soc. America J. 64, 1129-1136.

Dong, L.F., Smith, C.J., Papaspyrou, S., Stott, A., Osbom, A.M., and Nedwell, D.B. 2009. Changes in benthic denitrification, nitrate ammonification, and anammox process rates and nitrate and nitrite reductase gene abundances along an estuarine nutrient gradient (the Colne estuary, United Kingdom). Appl. Environ. Microbiol. 75, 3171-3179.

Ellis, M.J., Grossmann, J.G., Eady, R.R., and Hasnain, S.S. 2007. Genomic analysis reveals widespread occurrence of new classes of copper nitrite reductases. J. Biol. Inorg. Chem. 12, 1119-1127.

Enwall, K., Throback, I.N., Stenberg, M., Soderstrom, M., and Hallin, S. 2010. Soil resources influence spatial patterns of denitrifying communities at scales compatible with land management. Appl. Environ. Microbiol. 76, 2243-2250.

Fierer, N., Lauber, C.L., Ramirez, K.S., Zaneveld, J., Bradford, M.A., and Knight, R. 2012. Comparative metagenomic, phylogenetic and physiological analyses of soil microbial communities across nitrogen gradients. ISME J. 6, 1007-1017.

Findlay, S., Mulholland, P.J., Hamilton, S., Tank, J., Bemot, M., Burgin, A., Crenshaw, C., Dodds, W., Grimm, N., and McDowell, W. 2011. Cross-stream comparison of substrate-specific denitrification potential. Biogeochemistry 104, 381-392.

Fisher, S.G., Heffeman, J.B., Sponseller, R.A., and Welter, J.R. 2007. Functional ecomorphology: Feedbacks between form and function in fluvial landscape ecosystems. Geomorphology 89, 84-96.

Friedl, G. and Wüest, A. 2002. Disrupting biogeochemical cycles Consequences of damming. Aquatic Sci. 64, 55-65.

Frossard, A. 2011. Microbial dynamics during stream ecosystem succession: community structure and enzyme activities., Swiss Federal Institute of Technology Zurich, Switzerland.

Genkai-Kato, M., Mitsuhashi, H., Kohmatsu, Y., Miyasaka, H., Nozaki, K., and Nakanishi, M. 2005. A seasonal change in the distribution of a stream-dwelling stonefly nymph reflects oxygen supply and water flow. Ecol. Res. 20, 223-226.

Gergel, S.E., Carpenter, S.R., and Stanley, E.H. 2005. Do dams and levees impact nitrogen cycling? Simulating the effects of flood alterations on floodplain denitrification. Glob. Change Biol. 11, 1352-1367.

Graham, D.W., Trippett, C., Dodds, W.K., O'Brien, J.M., Banner, E.B.K., Head, I.M., Smith, M.S., Yang, R.K., and Knapp, C.W. 2010. Correlations between in situ denitrification activity and nir-gene abundances in pristine and impacted prairie streams. Environ. 
Pollut. 158, 3225-3229.

Grant, G.E., Schmidt, J.C., and Lewis, S.L. 2003. A peculiar river: Geology, geomorphology, and hydrology of the Deschutes river, Oregon, pp. 203-219. AGU, Washington DC, USA.

Groffman, P.M., Holland, E.A., Myrold, D.D., Robertson, G.P., and Zou, X. 1999. Standard soil methods for long-term ecological research. In Robertson, G.P., Bledsoe, C.S., Coleman, D.C., and Sollins, P. (eds.), pp. 272-290, Oxford University Press, New York, USA.

Groffman, P.M., Howard, G., Gold, A.J., and Nelson, W.M. 1996. Microbial nitrate processing in shallow groundwater in a riparian forest. J. Environ. Qual. 25, 1309-1316.

Hallin, S., Jones, C.M., Schloter, M., and Philippot, L. 2009. Relationship between N-cycling communities and ecosystem functioning in a 50-year-old fertilization experiment. ISME J. 3, 597 -605 .

Henry, S., Baudoin, E., López-Gutiérrez, J.C., Martin-Laurent, F., Brauman, A., and Philippot, L. 2004. Quantification of denitrifying bacteria in soils by nirK gene targeted real-time PCR. J. Microbiol. Methods 59, 327-335.

Hill, A.R., Devito, K.J., Campagnolo, S., and Sanmugadas, K. 2000. Subsurface denitrification in a forest riparian zone: Interactions between hydrology and supplies of nitrate and organic carbon. Biogeochemistry 51, 193-223.

Huang, S., Chen, C., Wu, Q., Zhang, R., and Yang, X. 2011. Distribution of typical denitrifying functional genes and diversity of the nirS-encoding bacterial community related to environmental characteristics of river sediments. Biogeosciences Discussions $\mathbf{8}$, 5251-5280.

IPCC. 2007. Climate change 2007: The physical science basis. Contribution of Working Group I to the fourth assessment report of the Intergovernmental Panel on Climate Change.

Jenkins, M.C. and Kemp, W.M. 1984. The coupling of nitrification and denitrification in two estuarine sediments. Limnol. Oceanogr. 29, 11.

Jones, C.M., Graf, D.R., Bru, D., Philippot, L., and Hallin, S. 2013. The unaccounted yet abundant nitrous oxide-reducing microbial community: a potential nitrous oxide sink. ISME J. 7, 417-426.

Jones, C.M. and Hallin, S. 2010. Ecological and evolutionary factors underlying global and local assembly of denitrifier communities. ISME J. 4, 633-641.

Jones, C.M., Stres, B., Rosenquist, M., and Hallin, S. 2008. Phylogenetic analysis of nitrite, nitric oxide, and nitrous oxide respiratory enzymes reveal a complex evolutionary history for denitrification. Mol. Biol. Evol. 25, 1955-1966.

Kandeler, E., Deiglmayr, K., Tscherko, D., Bru, D., and Philippot, L. 2006. Abundance of narG, nirS, nirK, and nosZ genes of denitrifying bacteria during primary successions of a glacier foreland. Appl. Environ. Microbiol. 72, 5957-5962.

Kang, H.J., Freeman, C., Lee, D., and Mitsch, W.J. 1998. Enzyme activities in constructed wetlands: implication for water quality amelioration. Hydrobiologia 368, 231-235.

Knapp, C.W., Dodds, W.K., Wilson, K.C., O'Brien, J.M., and Graham, D.W. 2009. Spatial heterogeneity of denitrification genes in a highly homogenous urban stream. Environ. Sci. Technol. 43, 4273-4279.

Kondolf, G.M., Boulton, A.J., O'Daniel, S., Poole, G.C., Rachel, F.J., Stanley, E.H., Wohl, E., Bang, A., Carlstrom, J., Cristoni, C., and et al. 2006. Process-based ecological river restoration: Visualizing three-dimensional connectivity and dynamic vectors to recover lost linkages. Ecol. Soc. 11, 5.
Kong, A.Y., Hristova, K., Scow, K.M., and Six, J. 2010. Impacts of different $\mathrm{N}$ management regimes on nitrifier and denitrifier communities and $\mathrm{N}$ cycling in soil microenvironments. Soil Biol. Biochem. 42, 1523-1533.

Leach, M. 2009. Influence of an upstream dam on riparian zone hydrology and shallow groundwater nitrate dynamics. Thesis, McMaster University, Hamilton, Ontario.

Lepš, J. and Šmilauer, P. 2003. Multivariate analysis of ecological data using CANOCO, Cambridge University Press.

Ligi, T., Truu, M., Truu, J., Nõlvak, H., Kaasik, A., Mitsch, W.J., and Mander, Ü. 2013. Effects of soil chemical characteristics and water regime on denitrification genes (nirS, nirK, and nosZ) abundances in a created riverine wetland complex. Ecol. Engineer., in press.

Lin, X., Tfaily, M.M., Green, S.J., Steinwegd, J.M., Chanton, P., Imvittaya, A., Chanton, J.P., Cooper, W., Schadt, C., and Kostk, J.E. 2014. Microbial metabolic potential for carbon degradation and nutrient (nitrogen and phosphorus) acquisition in an ombrotrophic peatland. Appl. Environ. Microbiol. 80, 3531-3540.

Liu, X.D., Tiquia, S.M., Holguin, G., Wu, L.Y., Nold, S.C., Devol, A.H., Luo, K., Palumbo, A.V., Tiedje, J.M., and Zhou, J.Z. 2003. Molecular diversity of denitrifying genes in continental margin sediments within the oxygen-deficient zone off the Pacific coast of Mexico. Appl. Environ. Microbiol. 69, 3549-3560.

Luo, J., Tillman, R., and Ball, P. 1999. Factors regulating denitrification in a soil under pasture. Soil Biol. Biochem. 31, 913-927.

Ma, W.K., Bedard-Haughn, A., Siciliano, S.D., and Farrell, R.E. 2008. Relationship between nitrifier and denitrifier community composition and abundance in predicting nitrous oxide emissions from ephemeral wetland soils. Soil Biol. Biochem. 40, 1114-1123.

Mackelprang, R., Waldrop, M.P., DeAngelis, K.M., David, M.M., Chavaria, K.L., Blazewicz, S.J., Rubin, E.M., and Jansson, J.K. 2011. Metagenomic analysis of a permafrost microbial community reveals a rapid response to thaw. Nature 480, 368-371.

Maingi, J.K. and Marsh, S.E. 2002. Quantifying hydrologic impacts following dam construction along the Tana River, Kenya. J. Arid Environ. 50, 53-79.

McClain, M.E., Boyer, E.W., Dent, C.L., Gergel, S.E., Grimm, N.B., Groffman, P.M., Hart, S.C., Harvey, J.W., Johnston, C.A., Mayorga, E., and et al. 2003. Biogeochemical hot spots and hot moments at the interface of terrestrial and aquatic ecosystems. Ecosystems $\mathbf{6}$, 301-312.

Miller, M.N., Zebarth, B.J., Dandie, C.E., Burton, D.L., Goyer, C., and Trevors, J.T. 2008. Crop residue influence on denitrification, $\mathrm{N}_{2} \mathrm{O}$ emissions and denitrifier community abundance in soil. Soil Biol. Biochem. 40, 2553-2562.

Mulholland, P.J., Helton, A.M., Poole, G.C., Hall, R.O., Hamilton, S.K., Peterson, B.J., Tank, J.L., Ashkenas, L.R., Cooper, L.W., Dahm, C.N., and et al. 2008. Stream denitrification across biomes and its response to anthropogenic nitrate loading. Nature 452, 202-246.

Myrold, D.D., Zeglin, L.H., and Jansson, J.K. 2013. The potential of metagenomic approaches for understanding soil microbial processes. Soil Sci. Soc. America J. 78, 3-10.

Nilsson, C., Reidy, C.A., Dynesius, M., and Revenga, C. 2005. Fragmentation and flow regulation of the world's large river systems. Science 308, 405-408.

Page, A.L. 1982. Methods of soil analysis. Part 2: Chemical and microbiological properties., Soil Science Society of America Madison, WI, USA.

Peralta, A.L., Matthews, J.W., and Kent, A.D. 2010. Microbial 
community structure and denitrification in a wetland mitigation bank. Appl. Environ. Microbiol. 76, 4207-4215.

Philippot, L., Andert, J., Jones, C.M., Bru, D., and Hallin, S. 2011. Importance of denitrifiers lacking the genes encoding the nitrous oxide reductase for $\mathrm{N}_{2} \mathrm{O}$ emissions from soil. Glob. Change Biol. 17, 1497-1504.

Philippot, L., Cuhel, J., Saby, N.P.A., Cheneby, D., Chronakova, A., Bru, D., Amouays, D., Martin-Laurent, F., and Simek, M. 2009. Mapping field-scale spatial patterns of size and activity of the denitrifier community. Environ. Microbiol. 11, 1518-1526.

Philippot, L. and Hallin, S. 2005. Finding the missing link between diversity and activity using denitrifying bacteria as a model functional community. Curr. Opin. Microbiol. 8, 234-239.

Philippot, L., Hallin, S., and Schloter, M. 2007. Ecology of denitrifying prokaryotes in agricultural soil. Adv. Agronomy 96, 249-305.

Pinardi, M., Bartoli, M., Longhi, D., Marzocchi, U., Laini, A., Ribaudo, C., and Viaroli, P. 2009. Benthic metabolism and denitrification in a river reach: a comparison between vegetated and bare sediments. J. Limnol. 68, 133-145.

Pinay, G., Black, V.J., Planty-Tabacchi, A.M., Gumiero, B., and Decamps, H. 2000. Geomorphic control of denitrification in large river floodplain soils. Biogeochemistry 50, 163-182.

Rastogi, G. and Sani, R. 2011. Molecular techniques to assess microbial community structure, function, and dynamics in the environment, pp. 29-57. In Ahmad, I., Ahmad, F., and Pichtel, J. (eds.), Microbes and microbial technology, Springer, New York, USA.

Rich, J.J., Heichen, R.S., Bottomley, P.J., Cromack, K., and Myrold, D.D. 2003. Community composition and functioning of denitrifying bacteria from adjacent meadow and forest soils. Appl. Environ. Microbiol. 69, 5974-5982.

Seitzinger, S., Harrison, J., Bohlke, J., Bouwman, A., Lowrance, R., Peterson, B., Tobias, C., and Van Drecht, G. 2006. Denitrification across landscapes and waterscapes: a synthesis. Ecol. Appl. 16, 2064 -2090 .

Skiba, U. and Smith, K.A. 2000. The control of nitrous oxide emissions from agricultural and natural soils. Chemosphere - Global Change Sci. 2, 379-386.

Smith, C.J. and Osbom, A.M. 2009. Advantages and limitations of quantitative PCR (q-PCR)-based approaches in microbial ecology. FEMS Microbiol. Ecol. 67, 6-20.

Smith, M.S. and Tiedje, J.M. 1979. Phases of denitrification following oxygen depletion in soil. Soil Biol. Biochem. 11, 7.

Solomon, C.T., Hotchkiss, E.R., Moslemi, J.M., Ulseth, A.J., Stanley, E.H., Hall, R.O., and Flecker, A.S. 2009. Sediment size and nutrients regulate denitrification in a tropical stream. J. North American
Benthological Society 28, 480-490.

Song, K., Lee, S.H., Mitsch, W.J., and Kang, H. 2010. Different responses of denitrification rates and denitrifying bacterial communities to hydrologic pulsing in created wetlands. Soil Biol. Biochem. 42, 1721 -1727 .

Stanley, E.H. and Doyle, M.W. 2002. A geomorphic perspective on nutrient retention following dam removal. BioScience 52, 693-701.

Starr, R.C. and Gillham, R.W. 1993. Denitrification and organic carbon availability in two aquifers. Ground Water 31, 934-947.

Stevenson, B.S. and Schmidt, T.M. 2004. Life history implications of rRNA gene copy number in Escherichia coli. Appl. Environ. Microbiol. 70, 6670-6677.

Strauss, E.A., Richardson, W.B., Cavanaugh, J.C., Bartsch, L.A., Kreiling, R.M., and Standorf, A.J. 2006. Variability and regulation of denitrification in an Upper Mississippi River backwater. J. North American Benthological Society 25, 596-606.

Stres, B., Danevcic, T., Pal, L., Fuka, M.M., Resman, L., Leskovec, S., Hacin, J., Stopar, D., Mahne, I., and Mandic-Mulec, I. 2008. Influence of temperature and soil water content on bacterial, archaeal and denitrifying microbial communities in drained fen grassland soil microcosms. FEMS Microbiol. Ecol. 66, 110-122.

Udy, J.W., Fellows, C.S., Bartkow, M.E., Bunn, S.E., Clapcott, J.E., and Harch, B.D. 2006. Measures of nutrient processes as indicators of stream ecosystem health. Hydrobiologia 572, 89-102.

Verbaendert, I., De Vos, P., Boon, N., and Heylen, K. 2011. Denitrification in Gram-positive bacteria: an underexplored trait. Biochem. Soc. Trans. 39, 254-258.

Vitousek, P.M., Aber, J.D., Howarth, R.W., Likens, G.E., Matson, P.A., Schindler, D.W., Schlesinger, W.H., and Tilman, D. 1997. Human alteration of the global nitrogen cycle: Sources and consequences. Ecol. Appl. 7, 737-750.

Wallenstein, M.D., Myrold, D.D., Firestone, M., and Voytek, M. 2006. Environmental controls on denitrifying communities and denitrification rates: Insights from molecular methods. Ecol. Appl. 16, 2143-2152.

Welti, N., Bondar-Kunze, E., Singer, G., Tritthart, M., Zechmeister-Boltenstem, S., Hein, T., and Pinay, G. 2012. Large-scale controls on potential respiration and denitrification in riverine floodplains. Ecol. Engineer. 42, 73-84.

Wohl, E.E. and Cenderelli, D.A. 2000. Sediment deposition and transport patterns following a reservoir sediment release. Water Resour. Res. 36, 319-333.

Zumft, W.G. 1997. Cell biology and molecular basis of denitrification. Microbiol. Mol. Biol. Rev. 61, 533-616. 